\title{
Lectio praecursoria, Information management in health care. A model for connecting information culture and patient safety
}

Virpi Jylhä, 20.1.2017

\section{Arvoisa kustos, arvoisa vastaväittäjä, arvoisat kuulijat,}

Potilas siirtyy erikoissairaanhoidosta terveyskeskuksen vuodeosastolle. Lääkitystietojen siirron yhteydessä jää huomiotta tieto, että lääke annostellaan kerran viikossa. Sairaanhoitaja merkitsee lääkkeen päivittäin annettavaksi. Virhe huomataan potilaan tilan heikentyessä.

Potilas joutuu sairaalaan. Potilasasiakirjoissa ei ole merkintää vasta-aiheista, joten lääkitys aloitetaan. Hoitavalla lääkärillä ei ole käytettävissä tietoa, että kyseinen lääkitys ei sovi potilaalle. Erehdys huomataan potilaan menehtyessä.

Edellä mainitut potilastapaukset ovat yksinkertaistettuja esimerkkejä tutkimusaineistostani. Yhteistä niille on se, että hoitavan ammattilaisen tekemän virheen tai erehdyksen taustalla myötävaikuttivat organisaatioiden käytännöt sekä työolosuhteet. Ensimmäisessä tapauksessa organisaatioiden välinen tiedonsiirto ei tapahtunut asianmukaisesti ja toisessa esimerkissä lääkärillä ei ollut tarvittavia potilastietoja käytettävissä puutteellisen tiedonvälityksen takia.

Hoitoon liittyvät haittatapahtumat ovat kansainvälisten arvioiden mukaan yleisiä, mutta luotettavaa tietoa haittatapahtumien määrästä ei ole saatavilla. Myöskään Suomessa haittatapahtumien todellista määrää ei ole tutkittu. Terveyden ja hyvinvoinnin laitoksen arvion mukaan potilaan kuolemaan johtavia haittatapahtumia tapahtuu 700 - 1700 vuosittain. Huomattavasti useampi potilas kärsii haittatapahtumista muun muassa pidentyneinä hoitoaikoina. Erään arvion mukaan joka kymmenes sairaalahoidossa oleva kohtaa vaaratilanteen. Tutkimusten mukaan näistä valtaosa on ennaltaehkäistävissä.

Toimiva tiedonhallinta on turvallisen ja laadukkaan hoidon edellytys. Hoitoon liittyvät päätökset tehdään käytettävissä olevan tiedon perusteella. Tämän vuoksi tiedonhallinnan ensisijainen tehtävä terveydenhuollossa onkin turvata oikea tieto, oikealle henkilölle, oikeaan aikaan, oikeassa paikassa ja muodossa. Se ei kuitenkaan ole yksinkertaista. Tänä päivänä meillä on käytössämme enemmän tietoa kuin koskaan aikaisemmin. Potilaan hoidossa tarvittavaa tietoa tuottavat niin terveydenhuollon ammattilaiset, potilaat itse kuin tutkijatkin. Sähköisen tiedonhallinnan menetelmien kehityksestä huolimatta edelleen haasteena on, kuinka potilaan hoidon kannalta olennainen tieto on hyödynnettävissä ajasta ja paikasta riippumatta silloin kun sitä tarvitaan.

Kolme vuotta sitten julkaistu vuoteen 2020 tähtäävä kansallinen "Sote-tieto hyötykäyttöön" -strategia linjaa, että on olennaista hyödyntää sosiaali- ja terveydenhuollossa syntyvää tietoa ja jalostaa se tietämykseksi, joka auttaa niin palvelujärjestelmää kuin yksittäistä kansalaistakin terveyden ja hyvinvoinnin edistämisessä.

Kehittämistyön painopisteen tulee siirtyä tiedon keräämisestä ja siirtämisestä siihen, että tietoa voidaan entistä paremmin hyödyntää muun muassa potilastyössä. On kuitenkin huomattava, että tiedonhallinnassa kaiken ydin on tiedon laatu. Tiedon hyödyntäminen edellyttää, että tieto on saatavilla, se on ajantasaista, hyvälaatuista ja merkityksellistä.

Hoitotyön tiedonhallinnan kehittäjät Graves and Corcoran määrittivät edellä mainitut ominaisuudet hyvän tiedon piirteiksi jo vuonna 1989 julkaistussa artikkelissaan. He myös totesivat, että hyvälaatuinen data tuottaa hyviä tuloksia, olettaen, että organisaatiossa on toimivat käytännöt datan prosessointiin. Voidaankin siis todeta, että hyvä ja toimiva tiedonhallinta edellyttää tehokkaita ja vaikuttavia prosesseja.

Tässä väitöskirjassa tiedonhallinta on määritetty professori Chun Wei Choon 2000-luvun alussa julkaiseman 
tiedonhallinnan prosessimallin mukaisesti kuuden toiminnan muodostamaksi, jatkuvasti eteneväksi monivaiheiseksi prosessiksi. Siihen kuuluvat tiedontarpeiden määrittely, tiedonhankinta, tiedon organisointi ja varastointi, tietotuotteiden ja -palveluiden kehittäminen, tiedon levittäminen sekä tiedon käyttö.

Hoitotyössä tiedon tarpeet nousevat potilaan hoitoon liittyvistä kysymyksistä. Niihin haetaan ratkaisuja hyödyntäen useita eri tiedonlähteitä, kuten potilastietoja, laboratorio- tai kuvantamistutkimusten tuloksia, hoitoon liittyviä suosituksia ja käytännön kokemusta. Saatu tieto on tallennettava järjestelmällisesti jatkokäyttöä varten tietovarastoon ennalta määritetyssä muodossa, kuten esimerkiksi sähköiseen potilaskertomukseen. Tallennettu tieto tulee koota tietotuotteiksi ja - palveluiksi tiedon hyödyntämistä varten. Tietotuote voi olla esimerkiksi potilaan hoidon yhteenveto tai näyttöön perustuva hoitosuositus. Tietopalvelu puolestaan on esimerkiksi tiedonhaun mahdollistava tietokanta.

Tiedon levittäminen tapahtuu suullisen tai kirjallisen viestinnän keinoin. Jälkimmäinen voi tapahtua sähköisesti tai manuaalisesti. Asianmukaisesti jaettu tieto mahdollistaa tiedon käytön hoitoon liittyvässä päätöksenteossa. Pitää myös tunnistaa mikä tieto on olennaista missäkin tilanteessa. Käytettävissä olevan tiedon laatu on täysin riippuvainen prosessin edellisten vaiheiden toteutumisesta.

Tiedonhallinta toteutuu kansallisella, alueellisella, organisaation ja kliinisen päätöksenteon tasolla. Tiedonhallinnan onnistuminen konkretisoituu potilaan ja terveydenhuollon ammattilaisen välisessä vuorovaikutuksessa - potilaan hoidon tuloksissa.

Suomessa terveydenhuollon tiedonhallinnan vaatimukset potilastietojen kirjaamiseen, käyttöön ja välittämiseen on määritetty lakien ja asetusten kautta. Kansallisen ohjeistuksen tulee näkyä alueellisella ja organisaation tasolla konkreettisina toimintaohjeina hoitoprosessin tiedonhallintaan. Kansallisen tason ohjaus muodostaa lainsäädännöllisen perustan organisaation tietokulttuurille.
Organisaation tietokulttuuri käsittää tiedonhallintaa ohjaavat arvot normit ja käytännöt. Tietokulttuuri määrittää kuinka tietoon suhtaudutaan organisaatiossa ja miten tietoa jaetaan ja hyödynnetään toiminnassa. Organisaation tiedonhallinnan käytännöt, tietokäyttäytyminen sekä tietoteknologian käytännöt määrittävät tietokulttuurin suuntautumisen. Yhdessä ne muodostavat edellytykset toimivalle ja tehokkaalle tiedon hyödyntämiselle päätöksenteossa.

Väitöskirjani keskittyy tiedonhallinnan käytäntöihin ja tietokäyttäytymiseen. Näistä ensimmäinen viittaa organisaation kykyyn hallita tietoa koko sen elämänkaaren ajan - tarpeen tunnistamisesta arkistointiin. Jälkimmäinen taasen viittaa tiedon tehokkaaseen käyttöön ohjaavan käyttäytymisen edistämiseen organisaatiossa. Tietokäyttäytyminen sisältää tiedon avoimeen jakamiseen, keskustelun läpinäkyvyyteen, sekä luottamukseen ja tiedon eheyteen liittyviä tekijöitä.

Tämä väitöskirja kohdistuu terveydenhuollon tiedonhallinnan tutkimusalalle. Terveydenhuollossa tiedonhallinnan toimintaympäristö muodostuu neljästä entiteetistä, tiedosta, toiminnasta, menetelmistä ja toimijoista.

Tässä yhteydessä tieto määritellään hierarkkiseksi jatkumoksi, tiedon arvoketjuksi, datasta viisauteen, jossa kompleksisuus ja verkostomaisuus lisääntyvät siirryttäessä yksinkertaisista data-yksiköistä, esimerkiksi numerot, kirjaimet tai symbolit, tiedon ja tietämyksen kautta viisauteen.

Toiminnalla tarkoitetaan terveydenhuollon palvelujen suunnittelua, toteutusta, käyttöä ja arviointia. Menetelmillä tarkoitetaan toiminnassa syntyneiden tietojen käsittelyyn, tallentamiseen ja välittämiseen liittyviä teknisiä ja sosiaalisia toimintatapoja. Toimijat ovat terveydenhuollon palveluja käyttäviä tai tuottavia henkilöitä tai yhteisöjä.

Tämä tutkimus kohdentuu terveydenhuollossa tarvittavan tiedon ja toiminnan väliseen suhteeseen eli toimintaprosesseissa tapahtuvan tiedonhallinnan ohjaukseen ja organisointiin. Tarkastelen tiedonhallintaa potilasturvallisuuden näkökulmasta. 
Tiedonhallinnan tutkimuksessa potilasturvallisuus on yksi nousevia teemoja. Globaalisti määritetyt potilasturvallisuustutkimuksen prioriteetit korostavat viestinnän puutteiden sekä piilevien organisaatiotekijöiden tunnistamista. Kuitenkin lisää tietoa tarvitaan tiedonhallinnan vaaratapahtumista ja niiden yhteydestä potilasturvallisuuteen, erityisesti haittatapahtumiin.

Terveydenhuollon vaaratapahtuma on potilaan turvallisuuden vaarantava tapahtuma, joka voi aiheuttaa haittaa potilaalle, kun taas haittatapahtumaksi kutsutaan tapahtumaa, joka aiheuttaa potilaalle haittaa. Tässä tapauksessa haitta voi aiheutua käytetystä lääkkeestä tai menetelmistä, sairaudesta tai poikkeamasta hoitoprosessissa. Tämä väitöskirjatutkimus kohdentuu jälkimmäisiin, ennaltaehkäistävissä oleviin haittatapahtumiin, jolloin poissuljettuja ovat esimerkiksi lääkkeiden asianmukaisesta käytöstä aiheutuneet odottamattomat haittavaikutukset.

Poikkeama, arkikielellä virhe, on mikä tahansa poikkeama sovitusta tai suunnitellusta poikkeava tapahtuma. Poikkeama voi olla myös potilaan edun mukainen. Suunnittelematon poikkeama voidaan jakaa lipsahduksiin ja erehdyksiin. Lipsahdus tarkoittaa suunnitelma virheellistä toteuttamista, kun taas erehdys viittaa virheelliseen suunnitelmaan. Poikkeaman taustalla vaikuttavat usein piilevät tekijät, kuten organisaation toimintakäytännöt ja yksikön työolosuhteet.

Tässä väitöskirjassa haittatapahtumien kehittyminen on jäsennetty professori James Reasonin kuvaaman niin kutsutun reikäjuustomallin kautta. Siinä piilevät tekijät on kuvattu organisaation ja työyksikön tasolla. Johdon päätökset sekä organisaatiokulttuuri luovat piileviä tekijöitä, jotka myötävaikuttavat haittatapahtuman syntyyn. Työyksikössä piileviä tekijöitä ovat tiedonhallintakäytännöt, turvallisuusilmapiiri, paikalliset työolosuhteet.

Terveydenhuollossa on rakennettu erilaisia suojauksia poikkeamien varalta - ne voivat olla teknisiä ratkaisuja, tai ihmisen toimia. Haittatapahtuma pääsee syntymään, mikäli suojaukset yksi kerrallaan pettävät ja läpäisevät niin sanotusti reikäjuuston, jolloin piilevä poikkeama pääsee ajan kuluessa aiheuttamaan haittatapahtuman potilaalle. Haittatapahtuma voi myös syntyä terveydenhuollon ammattilaisen välittömän toiminnan seurauksena, tällöin puhutaan aktiivista virheestä.

Jo 1990-luvun alkupuolella Australiassa toteutetussa potilasturvallisuustutkimuksessa todettiin, että järjestelmään liittyvät tekijät olivat pääasiallisena syynä neljännekseen haittatapahtumista. Jos huomioitiin myös organisaation liittyvien tekijöiden osittainen vaikutus, yli $90 \%$ haittatapahtumista aiheutui piilevän organisatorisen tekijän vaikutuksesta.

Kuitenkin, varsinainen ajattelutavan muutos, siirtyminen yksilön vastuuta korostavasta mallista organisaatiotekijöiden huomiointiin haittatapahtumien syntymisessä, tapahtui vasta $2000-l u v u n$ puolella. Tänä päivänä, puutteellinen viestintä on yleisesti tunnistettu haittatapahtumien syntyyn vaikuttava tekijä. Lisää tietoa tarvitaan siitä, miten tiedonhallinnan poikkeamia voidaan estää.

Väitöskirjatutkimukseni tavoitteena oli kehittää ja testata malli, joka yhdistää organisaation tietokulttuurin, tiedonhallintaan liittyvät vaaratilanteet sekä hoitoon liittyvät haittatapahtumat. Lisäksi tutkimuksen osatavoitteena oli tuottaa lisää tietoa tiedonhallintaan liittyvistä poikkeamista rekisteriaineistoon perustuen. Tutkimusaineisto koostui Valviran virallisista lausunnoista ja ratkaistuista kanteluista vuosilta 2001-2007, sairaalan vaaratapahtumien raportointijärjestelmään (HaiPro) kirjatuista ilmoituksista vuosilta 2008-2009 sekä vuonna 2010 toteutetusta, sairaanhoitajille kohdennetusta kyselytutkimuksesta, jossa mukana oli 32 sairaalaa. Kyselyn väittämät perustuivat rekisteriaineiston analyysin tuloksiin sekä aikaisempaan tutkimukseen.

Kehitetty malli jäsentyi Reason haittatapahtumien syntymistä kuvaavan reikäjuustomallin mukaisesti hyödyntäen hoitotyössä käytettyä rakenne-prosessi-tulos jäsennystä. Rakennetekijät eli tässä tutkimuksessa tietokulttuurin osa-alueet luovat olosuhteet, prosessi kuvaa toimintaa eli tässä tiedonhallinnan vaaratapahtumia ja tulokset viittaavat tiedonhallinnan tuloksiin eli tässä haittatapahtumiin ja läheltä piti -tilanteisiin. 
Tietokulttuurin osa-alueita kuvasivat seuraavat kolme rakennetekijää: 1) sähköisen potilaskertomuksen hyödyntäminen, 2) organisaation ohjaus sekä 3) tiedon saatavuus. Sähköisen potilaskertomuksen hyödyntäminen kuvaa sitä, kuinka organisaatiossa käytetään sähköistä potilaskertomusta. Kirjataanko tiedot pääsääntöisesti sähköisessä muodossa, siirretäänkö kertaalleen kirjattua tietoa järjestelmästä toiseen ja onko käytössä myös paperilla olevia potilastietoja.

Organisaation ohjaus kuvaa onko organisaatiossa yhtenäinen kirjallinen ohjeistus sähköisten potilastietojen käyttöön, siirtämiseen ja kirjaamiseen ja onko hoitohenkilökunta siitä tietoisia.

Tiedon saatavuus tarkoittaa onko kerran kirjattu tieto kaikkien terveydenhuollon ammattilaisten saatavilla, onko vastaajalla pääsy tarvittaviin tietokantoihin ja järjestelmiin ja luottaako hän tiedon oikeellisuuteen.

Tässä väitöskirjatutkimuksessa tunnistettiin neljä tiedonhallinnan vaaratapahtuman päätyyppiä: 1) kirjaamisvirheet, 2) viive tiedon välityksessä, 3) tiedon häviäminen vuoron vaihdon yhteydessä ja 4) tiedon häviäminen potilassiirron yhteydessä.

Mallissa tuloksia kuvanneet haittatapahtumat- ja läheltä piti -tilanteet sisälsivät lääkkeenantopoikkeamat, potilaiden tekemät kantelut sekä tiedonhallintaan liittyvät haittatapahtumat.
Kehitetyn mallin mukaan yhtenäinen ohjeistus sähköisen potilastiedon kirjaamisesta, välittämisestä sekä käytöstä vähensi kirjaamiseen liittyviä poikkeamia sekä tiedon häviämistä vuoron vaihdon ja potilaan siirron yhteydessä. Sähköisen potilaskertomuksen hyödyntäminen vähensi viiveitä tiedon välityksessä ja tiedon hyvä saatavuus vähensi tiedon häviämistä vuoron vaihdon ja potilassiirron yhteydessä.

Tiedonhallintaan liittyvistä vaaratapahtumista kirjaamisvirheet olivat voimakkaimmin yhteydessä haittatapahtumiin, mikä korostaa potilastiedon kirjaamisen tärkeyttä. Puutteellinen kirjaaminen lisää myös tiedon katoamista potilassiirtojen yhteydessä.

Yhteenvetona voidaan todeta, että organisaation tietokulttuuri vaikuttaa hoitotyössä tarvittavan tiedon hakuun, tallentamiseen, siirtoon ja käyttöön luoden olosuhteet, jotka mahdollistavat poikkeamien syntymisen. Organisaation asianmukaisella ohjeistuksella onkin merkittävä rooli turvallisessa tiedonhallinnassa. Täten sairaalan johdon tulee ottaa vahva rooli turvallisten tiedonhallintakäytäntöjen kehittämisessä yhteistyössä terveydenhuollon ammattilaisten kanssa. Kehittämistyön edellytyksenä on tiedonhallinnan prosessin kokonaisvaltainen ymmärtäminen.

Pyydän Teitä, arvoisa dosentti Pertti Mustajoki Yhteiskuntatieteiden ja kauppatieteiden tiedekunnan määräämänä vastaväittäjänä esittämään ne muistutukset, joihin katsotte väitöskirjani antavan aihetta.

Jylhä Virpi. 2017. Information Management in Health Care: A Model for Connecting Information Culture and Patient Safety. Publications of the University of Eastern Finland. Dissertations in Social Sciences and Business Studies N:o 140. University of Eastern Finland, Itä-Suomen yliopisto; 2016.

http://urn.fi/URN:ISBN:978-952-61-2384-4 